\title{
Analisis Hubungan Minat Belajar terhadap Hasil Belajar Daring IPA Siswa Kelas III Sekolah Dasar
}

\author{
Komang Suardi Wiradarma ${ }^{1}$, Ni Ketut Suarni ${ }^{2}$, Ndara Tanggu Renda ${ }^{3}$
}

1,2,3 Program Studi Pendidikan Guru Sekolah Dasar, FIP, Universitas Pendidikan Ganesha, Singaraja, Indonesia

\section{A R T I C L E I N F O}

\section{Article history:}

Received September 09, 2021

Revised September 15, 2021

Accepted September 30, 2021

Available online October 25, 2021

Kata Kunci:

Minat Belajar, Hasil Belajar Daring

\section{Keywords:}

Interest Learning, Online Learning Outcome

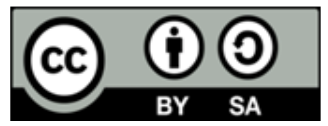

This is an open access article under the CC BY-SA license.

Copyright $(2021$ by Author. Published by Universitas Pendidikan Ganesha.

\begin{abstract}
A B S T R A K
Kesulitan guru dalam menumbuhkan minat belajar siswa dalam pembelajaran daring menyebabkan rendahnya hasil belajar siswa khususnya dalam pembelajaran IPA. Selama adanya pandemi COVID-19 pembelajaran di Indonesia dilakukan secara daring pada setiap jenjang pendidikan termasuk pada jenjang sekolah dasar. Sehingga diperlukan minat belajar siswa yang tinggi untuk mencapai hasil belajar yang maksimal. Penelitian ini bertujuan untuk menganalisis hubungan antara minat belajar terhadap hasil belajar daring IPA. Jenis penelitian ini adalah penelitian expost facto. Jumlah populasi dan sampel dalam penelitian in adalah 60 siswa. Teknik pengambilan data dengan menggunakan kuesioner. Analisis data yang digunakan adalah regresi sederhana dan regresi ganda dengan menggunakan SPSS. Hasil penelitian menunjukkan minat belajar dan hasil belajar saling mempengaruhi. Terjadi korelasi positif yang signifikan antara minat belajar dengan hasil belajar siswa yang memperoleh nilai $F_{\text {hitung }}>F_{\text {tabel }}(0,302>0,254)$. Jadi, terdapat hubungan yang signifikan antara minat belajar terhadap hasil belajar daring IPA siswa kelas III SD secara terpisah dan simultan. Semakin tinggi minat belajar siswa maka hasil belajar IPA siswa akan semakin meningkat. Implikasi dari penelitian ini adalah untuk meningkatkan kinerja guru serta peran aktif orangtua untuk menumbuhkan minat belajar siswa yang akan bermuara terhadap peningkatan hasil belajar siswa.
\end{abstract}

\section{A B S T R A C T}

The difficulty of teachers in fostering student interest in online learning causes low student learning outcomes, especially in science learning. During the COVID-19 pandemic, learning in Indonesia was carried out online at every level of education, including at the elementary school level. So it takes a high student interest in learning to achieve maximum learning outcomes. This study aims to analyze the relationship between learning interest on science online learning outcomes. This type of research is ex post facto research. The number of populations and samples in this study was 60 students. Data collection techniques using a questionnaire. The data analysis used is simple regression and multiple regression using SPSS. The results showed that interest in learning and learning outcomes influenced each other. There was a significant positive correlation between interest in learning and student learning outcomes who scored $F_{\text {count }}>F_{\text {table }}$ (0.302 > 0.254). So, there is a significant relationship between learning interest and online science learning outcomes for third grade students of Primary School Cluster III separately and simultaneously. The higher the student's interest in learning, the student's science learning outcomes will increase. The implication of this research is to improve teacher performance and the active role of parents to foster student interest in learning which will lead to improving student learning outcomes.

\section{PENDAHULUAN}

Pembelajaran IPA menuntut siswa aktif dalam pembelajaran serta diberikan kesempatan untuk mengalami dan menemukan sendiri tentang makna dari materi yang diajarkan (Lusidawaty et al., 2020; Mahmud et al., 2018; Meo et al., 2021; Prananda et al., 2020). Penanaman konsep-konsep dasar IPA dalam pembelajaran muatan IPA pada jenjang sekolah dasar bertujuan agar siswa mengetahui lingkungan sekitar serta dapat memecahkan masalah terkait kejadian alam yang sering terjadi. Ketertarikan siswa dalam mengikuti proses pembelajaran memerlukan bimbingan dalam belajar sehingga siswa memiliki minat untuk belajar. Pembelajaran IPA diharapkan dapat menjadi ajang bagi siswa untuk mempelajari dirinya sendiri dan alam sekitar, sehingga siswa dapat menerapkannya dalam kehidupan sehari-hari (Fransisca \& Mintohari, 2018; Roebianto, 2020). 
Ketercapaian hasil belajar siswa dipengaruhi oleh faktor internal dan faktor eksternal. Faktor yang berasal dari dalam diri orang yang belajar (internal) meliputi kesehatan, intelegensi dan bakat, minat dan motivasi, dan cara belajar serta ada pula dari luar dirinya (eksternal) meliputi lingkungan keluarga, sekolah, masyarakat, dan lingkungan sekitar (Awe \& Benge, 2017). Salah satu faktor dari dalam diri siswa yang mempengaruhi hasil belajar adalah minat belajar. Tanpa adanya minat belajar siswa untuk mendorong semangat belajar siswa akan berpengaruh terhadap rendahnya hasil belajar siswa (Karina et al., 2017; Riwahyudin, 2015). Oleh karena itu, diperlukan suatu pembelajaran yang dapat menarik minat siswa dalam belajar khususnya dalam pembelajaran IPA. Jadi, untuk meningkatkan hasil belajar siswa diperlukan minat belajar siswa yang menjadi penentu ketercapaian sasaran pembelajaran.

Kenyataan yang terjadi di sekolah dasar saat ini adalah siswa mengalami penurunan hasil belajar dikarenakan kurangnya minat belajar, mereka cenderung malas belajar karena kurangnya interaksi dengan lingkungan sekolah khususnya dalam pembelajaran IPA. Kebanyakan anak pada masa seperti sekarang ini berhubungan erat dengan teknologi karena teknologi dianggap lebih berwarna dari pada berinteraksi dengan lingkungan sekitar mereka (Safitri et al., 2020). Sebelumnya, hasil PISA (the programme for international student assessment) pada tahun 2018 yang dipublikasikan oleh Organization for Economic Cooperation and Development (OECD) menyatakan bahwa kategori kemampuan sains Indonesia berada di peringkat ke 71 dari 79 negara partisipan PISA dengan skor rata-rata 389 yang berada di bawah skor rata-rata Internasional yakni 500 (Hewi \& Shaleh, 2020). Hal ini terjadi karena adanya masalah dalam pembelajaran IPA yang mengakibatkan rendahnya hasil belajar siswa. Salah satu masalah dalam pembelajaran IPA adalah rendahnya minat belajar siswa yang menyebabkan rendanya keinginan siswa untuk belajar (Karina et al., 2017; Ningsih et al., 2018; S. Wulandari et al., 2017). Disisi lain, pembelajaran di Indonesia saat ini dilakukan secara daring (dalam jaringan) karena dampak pademi COVID-19. Coronavirus Diseases 2019 (COVID-19) adalah penyakit jenis baru yang memiliki tanda apabila seseorang terinfeksi menyebabkan munculnya gelaja umum gangguan pernapasan akut seperti demam, batuk, dan sesak napas (Dewi, 2020; Handayani et al., 2020; Kolta \& Ghonimy, 2020). Indonesia adalah salah satu negara yang turut terpapar virus ini sejak awal Maret hingga saat ini. Karena virus COVID-19 berbahaya, maka dilaksanakan pembelajaran jarak jauh atau secara daring (dalam jaringan) demi keselamatan tenaga pendidik dan peserta didik (Dewi, 2020; Malyana, 2020; Mulyanti et al., 2020). Oleh karena itu, diperlukan alat bantu pembelajaran yang dapat menarik minat siswa untuk belajar jarak jauh.

Wawancara dengan guru kelas menunjukkan bahwa minat belajar siswa selama proses pembelajaran daring masih rendah. Kendala yang dialami guru dalam menumbuhkan dan meningkatkan minat belajar siswa masih ditemukan dalam pembelajaran sekolah dasar. Meningkatnya minat belajar siswa diperlukan usaha dari guru untuk merancang pembelajaran yang dapat menumbuhkan kemauan siswa untuk belajar (Awe \& Benge, 2017; Colasante \& Douglas, 2016; Febriliani, 2018). Faktor-faktor yang mempengaruhi hasil belajar terdiri dari dua faktor yakni faktor internal dan eksternal. Faktor internal adalah faktor yang berasal dari dalam diri individu yang bersangkutan, yaitu; keadaan fisik dan psikis contohnya seperti gaya belajar, motivasi belajar, konsentrasi, raya percaya diri, intelegensi, kebiasaan belajar, dan lain-lain. Sedangkan faktor eksternal merupakan faktor yang berasal dari luar individu yang bersangkutan atau lingkungannya contohnya keluarga, sarana dan prasarana, kurikulum, dan lain-lain (Ricardo \& Meilani, 2017; Rumhadi, 2017). Faktor internal yang paling berperan merupakan minat belajar, karena minat belajar yang tinggi dapat mendorong siswa untuk aktif dan terdorong untuk belajar sehingga dapat mencapai hasil belajar (Rosiana, 2018). Minat belajar perpengaruh besar terhadap hasil belajar karena apabila terdapat minat belajar dalam diri siswa akan membuat siswa sungguhsungguh untuk belajar (Febriliani, 2018; Rosalina \& Junaidi, 2020). Apabila kenyataan yang terjadi dalam proses pembelajaran daring saat ini tidak segera ditanggulangi akan berdampak pada rendahnya kualitas sumber daya manusia dan kualitas pembelajaran IPA di Indonesia kedepannya.

Keberhasilan guru dalam meningkatkan minat belajar siswa dipengaruhi faktor internal dan faktor eksternal. Faktor internal merupakan faktor yang terdapat dalam diri siswa yang terdiri dari; kesehatan, dorongan, motif, dan emosional (Novika Auliyana et al., 2018; Prasetyo \& Nabillah, 2019). Pada faktor kesehatan, gangguan kesehatan dapat berpengaruh terhadap minat belajar siswa karena apabila siswa dalam keadaan sehat maka minat belajar siswa semakin meningkat. Pada faktor dorongan, perubahan sikap dapat terjadi apabila adanya dorongan dari dirinya sendiri. Pada faktor motif, keadaan dapat menimbulkan dorongan untuk melakukan kegiatan tertentu. Pada faktor emosional, siswa yang merasa berhasil dalam suatu hal akan bangga dan dapat memupuk minat untuk melakukan kembali hal tersebut. Faktor eksternal merupakan faktor dari luar diri siswa yang meliputi; bahan pelajaran dan sikap guru, keluarga, teman pergaulan, dan lingkungan. Pada faktor bahan pelajaran dan sikap guru, guru adalah salah satu objek yang dapat menumbuhkan minat belajar siswa dengan memperhatikan bahan pelajaran. Pada faktor keluarga, dukungan dan perhatian serta bimbingan dari keluarga sangan diperlukan untuk menumbuhkan minat belajar siswa khususnya dari orangtua. Pada faktor teman pergaulan, arah minat siswa sangat dipengaruhi oleh teman sepergaulannya. Pada faktor lingkungan, pertumbuhan dan perkembangan minat belajar siswa sangat dipengaruhi oleh lingkungannya (Karina et al., 2017). Menumbuhkan dan mengembangkan minat belajar siswa sangat diperlukan peran dari guru dan orangtua agar hasil belajar siswa dapat meningkat. Penelitian yang menyatakan bahwa hasil bahwa terdapat hubungan 
yang signifikan antara minat belajar siswa terhadap hasil belajar siswa(Budiwibowo, 2016; Karina et al., 2017; Ningsih et al., 2018; S. Wulandari et al., 2017). Penelitian yang menyatakan minat dapat memberikan dampak terhadap hasil belajar siswa (Awe \& Benge, 2017; Febriliani, 2018). Semakin tinggi minat siswa, maka semakin tinggi pula hasil belajar siswa (Radyuli \& Rahmat, 2017). Berdasarkah hal tersebut, untuk mengetahui sejauh mana hubungan minat belajar siswa terhadap hasil belajar daring IPA. Penelitian ini bertujuan untuk menganalisis hubungan antara minat belajar terhadap hasil belajar daring IPA. Melalui analisis hubungan antara minat belajar terhadap hasil belajar daring IPA siswa dapat menjadikan guru dan orangtua lebih memperhatikan faktor-faktor yang mempengaruhi minat belajar siswa. Kerjasama guru dan orangtua siswa untuk menumbuhkan minat belajar siswa dapat meningkatkan hasil belajar daring IPA siswa.

\section{METODE}

Jenis penelitian ini adalah penelitian expost facto yang mengkaji keterkaitan antara minat belajar siswa terhadap hasil belajar daring siswa pada muatan IPA. Dalam penelitian ini yang menjadi variabel bebas minat belajar, sedangkan variabel terikatnya adalah hasil belajar IPA siswa. Penelitian expost facto merupakan pendekatan tanpa suatu perlakuan guna memunculkan variabel yang ingin diteliti pada subjek penelitian (Juniarti et al., 2020; Rizqi \& Sumantri, 2019). Penelitian expost fakto bertujuan untuk mengungkap hubungan dua variabel atau lebih tanpa manipulasi (Sugiartini et al., 2019; Wulandari \& Renda, 2020). Penelitian ini dilakukan di SD Gugus III Kecamatan Gerokgak pada kelas III dengan jumlah populasi sebanyak 60 siswa. Populasi adalah himpunan dari unsur-unsur yang sejenis. Dalam populasi terdapat wilayah generalisasi yang terdiri atas objek/subjek yang mempunyai kualitas dan karakteristik tertentu yang ditetapkan oleh peneliti untuk dipelajari dan kemudian ditarik kesimpulan. Jadi populasi adalah seluruh siswa yang akan diteliti. Selain populasi dalam penelitian ini menggunakan sampel. Sampel ialah sebagian dari populasi yang diambil, yang dianggap mewakili populasi dan diambil dengan menggunakan teknik tertentu (Anggraini et al., 2017). Dengan demikian sampel adalah sebagian dari populasi yang ditentukan oleh peneliti untuk dipelajari dan kemudian ditarik kesimpulan. Dalam penelitian ini sampel diambil menggunakan teknik sampling random. Dari teknik tersebut maka ditetapkan jumlah sampel penelitian yakni 60 siswa.

Metode pengumpulan data dilakukan untuk mencari data pendukung dalam sebuah penelitian. Metode yang digunakan dalam penelitian ini meliputi data minat belajar dan data hasil belajar. Metode yang digunakan dalam pengumpulan menggunakan metode pencatatan dokumen untuk hasil belajar dan metode pengumpulan data pola asuh dan motivasi menggunakan metode non tes. Metode non tes berupa kuesioner/angket. Metode kuesioner/angket merupakan cara memperoleh atau mengumpulkan data dengan mengirimkan suatu daftar pertanyaan/pernyataan- pernyataan kepada responden/subjek penelitian (Agung, 2014). Jadi kuesioner dapat diartikan teknik yang menggunakan sebuah pernyataan-pernyataan yang nantinya dijawab oleh responden dengan tujuan mengumpulkan keterangan sesuai dengan kenyataan atau data yang berkaitan dengan penelitian. Berikut disajikan kisi-kisi instrumen kuesioner minat belajar pada Tabel 1.

Tabel 1. Kisi-kisi Instrumen Minat Belajar

\begin{tabular}{clcccc}
\hline Variabel & Indikator & Nomor Butir Soal & \multicolumn{2}{c}{ Butir Soal } & \multirow{2}{*}{ Jumlah Butir Soal } \\
\cline { 4 - 5 } & & & $\mathbf{( + )}$ & $\mathbf{( - )}$ & \\
\hline Minat & Perasaan senang & $1,4,5,7,9$ & $1,4,5$ & 7,9 & 5 \\
Belajar & Ketertarikan siswa & $2,3,6,8,10$ & $3,8,10$ & 2,6 & 5 \\
& Perhatian siswa & $11,12,14,17,18$ & $11,14,17$ & 12,18 & 5 \\
& Keterlibatan siswa & $13,15,16,19,20$ & $13,19,20$ & 15,16 & 5 \\
\hline
\end{tabular}

Teknik analisis data yang digunakan adalah analisis product moment. Pada saat pengujian hipotesis yang berbunyi "hubungan yang signifikan minat belajar dengan hasil belajar daring IPA siswa" menggunakan analisis product moment dengan membangdingkan nilai $r_{\text {hitung }}>r_{\text {tabel. }}$. Apabila nilai $r_{\text {hitung }}$ lebih besar dari nilai $r_{\text {tabel }}$ maka terdapat korelasi yang signifikan antara minat belajar dengan hasil belajar dengan $\mathrm{H}_{0}$ ditolak dan $\mathrm{H}_{a}$ diterima. Namun apabila nilai $r_{\text {hitung }}$ lebih kecil dari nilai $r_{\text {tabel }}$ maka tidak terdapat korelasi yang signifikan antara minat belajar dengan hasil belajar dengan $\mathrm{H}_{0}$ diterima dan $\mathrm{H}_{\mathrm{a}}$ ditolak.

\section{HASIL DAN PEMBAHASAN}

Hasil

Data yang diperoleh dari hasil penelitian ini adalah data hasil kuesioner minat belajar siswa kelas III SD gugus III Kecamatan Gerokgak yang dijadikan sampel dalam penelitian ini, hasil belajar IPA siswa kelas III yang bersumber dari pencatatan dokumen hasil belajar siswa. Data mengenai minat belajar siswa kelas III SD Gugus III Kecamatan Gerokgak melalui pengisian kuesioner yang disebarkan ke sekolah-sekolah dengan meminta ijin 
kepada guru wali kelas masing-masing. Penyebaran kuesioner sesuai dengan jumlah responden sebanyak 60 responden dan diberikan 20 butir pernyataan. Hasil penyebaran kuesioner minat belajar disajikan melalui Tabel 2.

Tabel 2. Deskripsi Data Nilai Minat Belajar dan Hasil Belajar Siswa Kelas III SD Gugus III Kecamatan Gerokgak

\begin{tabular}{ccc}
\hline Data Statistik & Nilai Minat Belajar & Nilai Hasil Belajar \\
\hline Mean & 87.23 & 81,478 \\
Standar Deviasi & 6.853 & 5,344 \\
Skor Maksimum & 100 & 28,558 \\
Skor Minimum & 69 & 72 \\
Varians & 46.962 & 95 \\
\hline
\end{tabular}

Data Minat Belajar pada Tabel 2 menunjukkan distribusi frekuensi dapat diketahui bahwa frekuensi nilai terbanyak terdapat pada kelas interval ke- 86 - 90 dengan rentang nilai 88,5 sebanyak 38,3\%. Data yang diperoleh tersebut dianalisis untuk mengetahui rata-rata (Mean), nilai tengah (Median), dan nilai-nilai yang sering muncul (Modus). Adapun hasil perhitungan tersebut didapatkan nilai rata-rata (mean) Sebesar $(87,23)$. Nilai tengah (median) sebesar 88,37. Nilai yang sering muncul (modus) sebesar 88,8 selanjutnya untuk mengetahui kualitas variabel minat belajar diperoleh rata-rata ideal $\left(M_{i}\right)$ sebesar 60 dan standar deviasi ideal $\left(S D_{i}\right)$ sebesar 13. hasil dari analisis data, bahwa rerata dari konsep minat belajar siswa kelas III SD Gugus III kecamatan Gerokgak sebesar 87,23. Berdasarkan data tersebut maka dapat disimpulkan bahwa nilai minat belajar siswa kelas III SD Gugus III Kecamatan Gerokgak tergolong sangat baik.

Hasil analisis data hasil belajar IPA berupa rata-rata skor hasil belajar, standar deviasi, skor minimum, skor maksimum, dan jangkauan yang diolah dengan bantuan SPSS, yang dirangkum pada Tabel 2 bahwa skor Hasil Belajar IPA dibagi kedalam 6 kelas. Responden yang memiliki skor dengan interval (72 $75)$. Sebanyak 5 orang responden yang memiliki skor dengan interval (76-80) sebanyak 31 orang, responden yang memiliki skor interval (81 - 84) sebanyak 8 orang, responden yang memiliki skor interval (85 - 88) sebanyak 9 orang, responden yang memilik skor interval (89-92) sebanyak 3 orang, responden yang memiliki skor interval (93 - 96) sebanyak 4 orang. Sehingga dapat dilihat sebagian besar skor yang diperoleh responden berada pada interval (76 - 80) yaitu sebanyak 31 orang. Dari data diatas dapat dianalisis untuk mengetahui mean, median, dan modus. Adapun hasilnya adalah mean sebesar (81.47), media sebesar (80), dan Modus sebesar (80). Hasil data Klasifikasi tersebut menunjukkan bahwa rerata hasil belajar sebesar 81,47 berdasarkan data tersebut dapat disimpulkan data tersebut tergolong sangat baik.

Uji prasyarat analisis dilakukan terlebih dahulu sebelum uji hipotesis, data yang diperoleh terlebih dahulu dilakukan uji normalitasnya. Hasil pengujian normalitas data hasil belajar IPA, dan minat belajar memperoleh nilai Asymp.Sig (2-tailed) 0,153>0,05 pada variabel minat belajar dengan hasil belajar yang berarti data minat berdistribusi normal. Berdasarkan perhitungan dengan menggunakan Kolmogorov Smirnov, diperoleh data hasil distribusi normal. Setelah melakukan uji normalitas selanjutnya melakukan uji linieritas. Uji linieritas digunakan untuk mengetahui hubungan antara variabel bebas dengan variabel terikat. Uji linieritas pada penelitian ini dilakukan dengan bantuan SPSS. Pengambilan keputusan dari uji linieritas adalah jika nilai signifikansi (deviation from linearity) $>0,05$, maka terdapat hubungan yang linier antara variabel bebas dengan variabel terikat. Jika nilai signifikansi $<0,05$, maka tidak terdapat hubungan yang linier antara variabel bebas dengan variabel terikat. Pada minat belajar terdapat hasil linieritas sebesar 0,305 maka dapat diartikan data tersebut terdapat hubungan yang linier.

Setelah dilakukan uji prasyarat dan semua uji prasyarat sudah terpenuhi maka dilanjutkan dengan pengujian hipotesis. Adapun uji yang digunakan adalah uji analisis product moment. Setelah melakukan uji signifikansi koefisien rumus analisis product moment diperoleh hasil $\mathrm{r}_{\mathrm{xy}}=0,302$. Untuk uji signifikansi koefisien korelasi, digunakan nilai tabel product moment $(\mathrm{r})$ untuk $\mathrm{n}=60$, Nilai rtabel untuk $\mathrm{n}=60$ adalah 0,254 . Maka dapat dinyatakan $r_{\text {hitung }}>r_{\text {tabel. }}$ Ini menyatakan bahwa nilai rhitung signifikan dengan nilai 0,302 sehingga H0 yang berbunyi tidak terdapat korelasi yang signifikan antara Minat belajar dengan hasil belajar IPA kelas III SD Gugus III Kecamatan Gerokgak Kabupaten Gerokgak ditolak, dan Ha diterima. Hal ini menunjukkan bahwa terjadi korelasi positif yang signifikan antara minat belajar dengan hasil belajar siswa. Jadi dapat diinterpretasikan bahwa semakin tinggi minat belajar siswa maka hasil belajar IPA siswa akan semakin meningkat. Hasil pengujian hipotesis menunjukkan bahwa terdapat hubungan yang signifikan antara minat belajar siswa terhadap hasil belajar daring IPA siswa kelas III Gugus III Kecamatan Gerokgak. Nilai koefisien korelasi sebesar 0,302 dikategorikan signifikan apabila dibandingkan dengan nilai tabel product moment untuk $\mathrm{n}=60$ yang sebesar 0,254 . 


\section{Pembahasan}

Hasil dari penelitian ini dinyatakan terdapat hubungan yang signifikan antara minat belajar dengan hasil belajar IPA siswa kelas III SD Gugus III Kecamatan Gerokgak Kabupaten Buleleng. Jadi dapat diinterpretasikan bahwa minat belajar siswa sangatlah berpengaruh terhadap hasil belajar siswa karena tumbuhnya minat belajar dalam diri siswa akan mendorong siswa untuk mengikuti pembelajaran dengan baik. Semakin tinggi minat belajar siswa akan meningkatkan hasil belajar siswa. Tenaga pendidik memiliki peran yang sangat penting dalam menumbuhkan minat belajar siswa disamping peran serta orangtua (Budiwibowo, 2016). Selama pembelajaran daring, guru dituntut untuk menciptakan kegiatan belajar mengajar yang menarik dan bermakna agar dapat menumbuhkan minat siswa dalam belajar (Chang et al., 2020; Daheri et al., 2020; Permata \& Bhakti, 2020; Pratiwi, 2020). Hal ini dapat dilihat dari beberapa indicator. Pertama, perasaan senang, minat belajar yang baik mencerminkan ketertarikan sehingga terdapat perubahan hasil belajar sesuai dengan harapan siswa dan guru. Perasaan senang siswa dalam mengikuti proses belajar di sekolah dapat menjadikan siswa lebih menyukai kegiatan dalam belajar (Budiwibowo, 2016; Laksono et al., 2016). Beberapa siswa memberikan respon senang selama mengikuti pembelajaran daring karena proses pembelajaran tidak membosankan. Sehingga siswa merasa lebih tertarik mengikuti proses pembelajaran. Siswa yang memiliki minat belajar tinggi akan merasa senang dalam mengikuti proses pembelajaran (Ya-hsunTsai et al., 2018). Selain itu adanya minat yang tinggi mampu mengarahkan siswa dalam mengikuti kegiatan pembelajaran dengan baik (Mayang Ayu Sunami \& Aslam, 2021; Ningsih et al., 2018; Sari et al., 2019).

Kedua perhatian, minat belajar siswa dapat meningkat apabila ada kerja sama antara guru dengan orang tua. Kerjasama yang dimaksud yaitu pemberian perhatian dan pendampingan selama pembelajaran daring. Perhatian orang tua dan guru sudah diupayakan dengan baik sehingga dapat meningkatkan minat belajar siswa. Akibat pandemi covid-19 pembelajaran dilaksanakan secara daring (Atmojo \& Nugroho, 2020; Baber, 2021; Steven, 2014). Hal ini mengakibatkan peran orang tua dan guru sangat berpengaruh terhadap minat belajar siswa. Bentuk perhatian orang tua yang dapat diberikan orang tua untuk anaknya berupa pemberian bimbingan belajar, memberikan pengawasan selama pembelajaran di rumah, mefasilitasi anak selama pembelajaran daring agar terciptanya suasana belajar yang tenang dan nyaman bagi anak. Hal tersebut dilakukan karena proses pembelajaran dilakukan dirumah masing-masing dan tidak langsung di sekolah. Oleh karena itu perhatian orang tua sangat sangat diperlukan (Handayani, 2017; Mulyani et al., 2021).

Ketiga kemauan, beberapa siswa mengalami kesulitan dalam memahami materi pembelajaran yang diberikan guru selama pembelajaran daring. Namun, beberapa siswa memiliki mempunyai inisiatif untuk mengatasi kesulitan yang dialami. Kesulitan itu dapat diatasi dengan bertanya kepada guru atau orang tua siswa yang mendampingi selama proses pembelajaran. hal itu menunjukkan adanya kemauan dalam belajar untuk mengatasi masalah tersebut. Minat mejadi faktor terpenting dalam proses pembelajaran. Adanya minat yang besar dapat mempengaruhi cara belajar siswa. Selain itu, bahan pelajaran dan metode pembelajaran yang menarik minat siswa, akan lebih mudah dipelajari dan disimpan oleh siswa (Laksono et al., 2016; Pangesti et al., 2017). Hal ini disebabkan karena minat selalu berkaitan dengan perhatian, perasaan senang, dan adanya kemauan. Minat belajar siswa sangatlah berpengaruh terhadap hasil belajar siswa karena tumbuhnya minat belajar dalam diri siswa akan mendorong siswa untuk mengikuti pembelajaran dengan baik. Semakin tinggi minat belajar siswa akan meningkatkan hasil belajar siswa. Tenaga pendidik memiliki peran yang sangat penting dalam menumbuhkan minat belajar siswa disamping peran serta orangtua (Budiwibowo, 2016; Haryaka, U., 2019; Yulianingsih et al., 2020). Selama pembelajaran daring, guru dituntut untuk menciptakan kegiatan belajar mengajar yang menarik dan bermakna agar dapat menumbuhkan minat siswa dalam belajar (Chang et al., 2020; Daheri et al., 2020; Permata \& Bhakti, 2020; Pratiwi, 2020).

Hasil penelitian ini didukung penelitian yang menyatakan bahwa ada hubungan yang signifikan antara variabel minat belajar IPA (X) dengan hasil belajar IPA (Y). Semakin tinggi minat belajar siswa maka makin tinggi pula hasil belajar yang didapatkan, sebaliknya semakin rendah minat belajar siswa maka semakin rendah pula hasil belajar yang didapatkan oleh siswa(Sidiq et al., 2020). Selain itu, penelitian menyatakan bahwa terdapat hubungan antara minat dengan hasil belajar peserta didik SDN 25 Jati Tanah Tinggi (Sari et al., 2019). Penelitian ini juga diperkuat penelitian yang menyatakan terdapat hubungan yang signifikan antara minat belajar siswa pada mata pelajaran IPS dengan hasil belajar siswa (Budiwibowo, 2016). Kelebihan penelitian ini adalah dapat menghasilkan informasi mengenai hubungan antara minat belajar terhadap hasil belajar siswa. Melalui informasi tersebut dapat dijadikan sebagai bahan perbaikan dalam pembelajaran dengan memperhatikan faktor-faktor yang dapat menumbuhkan minat belajar siswa sehingga dapat meningkatkan hasil belajar IPA siswa. Kelemahan penelitian ini adalah tidak terdapat kontrol terhadap minat belajar sehingga lebih sulit untuk memperoleh kepastian mengenai hubungan antara minat belajar terhadap hasil belajar siswa. Hasil penelitian berupa informasi mengenai hubungan minat belajar terhadap hasil belajar siswa dapat memberikan kontribusi dalam dunia pendidikan berupa faktor-faktor yang dapat menumbuhkan minat belajar siswa sebagai langkah untuk memperbaiki kualitas pendidikan di Indonesia. Implikasi penelitian ini dapat meningkatkan kinerja guru serta peran aktif orangtua untuk memperhatikan dan menumbuhkan minat belajar siswa sehingga siswa dapat mencapai hasil belajar yang maksimal. Keterbatasan penelitian ini terdapat pada variabel bebas yang tidak dapat 
dikontrol, peneliti harus mengambil fakta-fakta yang dijumpai tanpa kesempatan untuk mengatur kondisikondisinya atau memanipulasikan variabel-variabel yang mempengaruhi fakta-fakta yang dijumpai. Sehingga disarankan untuk peneliti lain untuk melakukan penelitian serupa dengan variabel bebas lainnya yang berpengaruh terhadap hasil belajar siswa.

\section{SIMPULAN}

Berdasarkan hasil analisis dapat disimpulkan bahwa minat belajar siswa memiliki hubungan yang positif dan signifikan dengan hasil belajar daring IPA siswa. Semakin tinggi minat belajar siswa maka semakin meningkat pula hasil belajar daring IPA siswa. Faktor-faktor yang mempengaruhi minat belajar dapat dijadikan tolak ukur untuk meningkatkan hasil belajar siswa khususnya pada pembelajaran IPA secara daring. Direkomendasikan kepada orang tua dan guru untuk selalu memberikan motivasi dan mendampingi anak selama belajar daring sehingga dapat meningkatkan hasil belajar siswa khususnya pembelajaran IPA.

\section{DAFTAR PUSTAKA}

Agung, A. A. G. (2014). Metode Penelitian Pendidikan. Aditya Media Publishing.

Agus Abhi Purwoko, Burhanuddin, Yayuk Andayani, Saprizal Hadisaputra, Lian Yulianti, Zelisa Nudia Fitri, D. P. (2021). Validitas Instrumen Dalam Rangka Pengembangan Metode Pembelajaran Inovatif Untuk Meningkatkan Minat Belajar Siswa. Prosiding SAINTEK Universitas Mataram, 3(0), 94-102. https://jurnal.lppm.unram.ac.id/index.php/prosidingsaintek/article/view/271.

Anggraini, Hartuti, P., \& Sholihah, A. (2017). Hubungan Pola Asuh Orang Tua Dengan Kepribadian Siswa SMA Di Kota Bengkulu. Consilia: Jurnal Ilmiah Bimbingan Dan Konseling, 1(1), 10-18. https://doi.org/10.33369/consilia.1.1.10-18 https://doi.org/10.33369/consilia.1.1.10-18.

Atmojo, A. E. P., \& Nugroho, A. (2020). EFL classes must go online! Teaching activities and challenges during COVID-19 pandemic in Indonesia. Register Journal, 13(1), 49-76. https://doi.org/10.18326/rgt.v13i1.49-76

Awe, E. Y., \& Benge, K. (2017). Hubungan Antara Minat Dan Motivasi Belajar Dengan Hasil Belajar Ipa Pada Siswa Sd. Journal of Education Technology, 1(4), 231. https://doi.org/10.23887/jet.v1i4.12859.

Baber, H. (2021). Modelling the acceptance of e-learning during the pandemic of COVID-19-A study of South Korea. The International Journal of Management Education, 19(2), 100503. https://doi.org/10.1016/j.ijme.2021.100503.

Budiwibowo, S. (2016). Hubungan Minat Belajar Siswa Dengan Hasil Belajar Ips Di Smp Negeri 14 Kota Madiun. Gulawentah:Jurnal Studi Sosial, 1(1), 60. https://doi.org/10.25273/gulawentah.v1i1.66.

Chang, T. Y., Hong, G., Paganelli, C., Phantumvanit, P., Chang, W. J., Shieh, Y. S., \& Hsu, M. L. (2020). Innovation of dental education during COVID-19 pandemic. Journal of Dental Sciences, 155. https://doi.org/10.1016/j.jds.2020.07.011.

Colasante, M., \& Douglas, K. (2016). Prepare-participate-connect: Active learning with video annotation. Australasian Journal of Educational Technology, 32(4), 68-91. https://doi.org/10.14742/ajet.2123.

Daheri, M., Juliana, J., Deriwanto, D., \& Amda, A. D. (2020). Efektifitas WhatsApp sebagai Media Belajar Daring. Jurnal Basicedu, 4(4), 775-783. https://doi.org/10.31004/basicedu.v4i4.445.

Dewi, W. A. F. (2020). Dampak COVID-19 terhadap Implementasi Pembelajaran Daring di Sekolah Dasar. Edukatif : Jurnal Ilmu Pendidikan, 2(1), 55-61. https://doi.org/10.31004/edukatif.v2i1.89.

Febriliani, L. (2018). Hubungan Minat Belajar Dan Fasilitas Belajar Terhadap Hasil Belajar Matematika Kelas V. Joyful Learning Journal, 7(2), 10-18. https://doi.org/10.15294/jlj.v7i2.24049.

Fransisca, I., \& Mintohari. (2018). Pengembangan Media Pembelajaran Video Berbasis Sparkol Videoscribe Pada Pelajaran Ipa Dalam Materi Tata Surya Kelas Vi SD. Jurnal Penelitian Pendidikan Guru Sekolah Dasar, 6(11), 1916-1927. https://jurnalmahasiswa.unesa.ac.id/index.php/39/article/view/24661/22575.

Handayani. (2017). Pengaruh Perhatian Orang Tua Dan Konsep Diri Siswa Terhadap Hasil Belajar Matematika Siswa. Jurnal Pendidikan Dasar, 8(1). http://journal.unj.ac.id/unj/index.php/jpd/article/view/5347.

Handayani, D., Hadi, D. R., Isbaniah, F., Burhan, E., \& Agustin, H. (2020). Corona virus disease 2019. Jurnal Respirologi Indonesia, 40(2), 119-129. https: //doi.org/10.36497/jri.v40i2.101.

Haryaka, U., H. (2019). Pengaruh Konsep Diri, Minat dan Sikap Ilmiah Siswa terhadap Hasil Belajar Matematika. PRISMA, Prosiding Seminar Nasional Matematika, $2, \quad 737-774$. https://journal.unnes.ac.id/sju/index.php/prisma/article/view/29261.

Hewi, L., \& Shaleh, M. (2020). Refleksi Hasil PISA (The Programme For International Student Assesment): Upaya Perbaikan Bertumpu Pada Pendidikan Anak Usia Dini). Jurnal Golden Age, 4(01), 30-41. https://doi.org/10.29408/jga.v4i01.2018.

Juniarti, N. K. R., Margunayasa, I. G., \& Kusmariyatni, N. (2020). Hubungan Antara Pola Asuh Orang Tua dan Konsep Diri dengan Kompetensi Pengetahuan Matematika Siswa. Jurnal Ilmiah Sekolah Dasar, 4(1), 17. 
https://doi.org/10.23887/jisd.v4i1.24273.

Karina, R. M., Syafrina, A., \& Habibah, S. (2017). Hubungan Antara Minat Belajar Dengan Hasil Belajar Siswa Dalam Mata Pelajaran Ipa Pada Kelas V Sd Negeri Garot Geuceu Aceh Besar. Jurnal Ilmiah Pendidikan $\begin{array}{llll}\text { Guru Sekolah } & \text { Dasar, } & \text { 61-77), }\end{array}$ https://journal.unnes.ac.id/sju/index.php/prisma/article/view/29261.

Kolta, M. F., \& Ghonimy, M. B. I. (2020). COVID-19 variant radiological findings with high lightening other coronavirus family (SARS and MERS) findings: radiological impact and findings spectrum of corona virus (COVID-19) with comparison to SARS and MERS. Egyptian Journal of Radiology and Nuclear Medicine, 51(1). https://doi.org/10.1186/s43055-020-00262-7.

Laksono, Y. S., Ariyanti, G., \& Santoso, F. G. I. (2016). Hubungan Minat Belajar Siswa Terhadap Prestasi Belajar Matematika Siswa Dalam Pembelajaran Kooperatif Tipe Stad Menggunakan Komik. Jurnal Edukasi Matematika Dan Sains, 1(2), 60-64. https: //doi.org/10.25273/jems.v1i2.143.

Lusidawaty, V., Fitria, Y., Miaz, Y., \& Zikri, A. (2020). Pembelajaran IPA Dengan Strategi Pembelajaran Inkuiri Untuk Meningkatkan Keterampilan Proses Sains Dan Motivasi Belajar Siswa Di Sekolah Dasar. Jurnal Basicedu, 4(1), 168-174. https://doi.org/10.31004/basicedu.v4i1.333.

Mahmud, S. N. D., Nasri, N. M., Samsudin, M. A., \& Halim, L. (2018). Science teacher education in Malaysia: challenges and way forward Siti. Asia-Pacific Science Education ORIGINAL, 4(8), 153-155. https://doi.org/10.1186/s41029-018-0026-3.

Malyana, A. (2020). Pelaksanaan Pembelajaran Daring Dan Luring Dengan Metode Bimbingan Berkelanjutan Pada Guru Sekolah Dasar Di Teluk Betung Utara Bandar Lampung. Pedagogia: Jurnal Ilmiah Pendidikan Dasar Indonesia, 2(1), 67-76. https: //doi.org/10.52217/pedagogia.v2i1.640.

Mayang Ayu Sunami, \& Aslam. (2021). Pengaruh Penggunaan Media Pembelajaran Video Animasi Berbasis Zoom Meeting terhadap Minat dan Hasil Belajar IPA Siswa Sekolah Dasar. Jurnal Basicedu, 5(4), 1-9. https://doi.org/10.31004/basicedu.v5i4.1129.

Meo, L., We'u, G., \& BS, Y. N. (2021). Penerapan Model Pembelajaran Inkuiri Dalam Meningkatkan Hasil Belajar IPA Pada Siswa Sekolah Dasar. Jurnal Ilmiah Pendidikan Citra Bakti, 8(1), 38-52. https://doi.org/https://doi.org/10.38048/jipcb.v8i1.97.

Mulyani, E. R., Masrul, \& Astuti. (2021). Analisis Perhatian Orang Tua terhadap Minat Belajar Siswa Kelas IV Sekolah Dasar pada Masa Pandemi Covid 19. Jurnal Pendidikan Tambusai, 5(2), 261-266.

Mulyanti, B., Purnama, W., \& Pawinanto, R. E. (2020). Distance learning in vocational high schools during the covid-19 pandemic in West Java province, Indonesia. Indonesian Journal of Science and Technology, 5(2), 271-282. https://doi.org/10.17509/ijost.v5i2.24640.

Ningsih, N. L. P. R., Darsana, I. W., \& Abadi, I. B. G. S. (2018). Korelasi Antara Minat Belajar dengan Hasil Belajar IPS. Mimbar PGSD Undiksha, 6(3), 202-209. https://doi.org/10.23887/jjpgsd.v6i3.21097.

Novika Auliyana, S., Akbar, S., \& Yuniastuti. (2018). Penerapan Pembelajaran Tematik Terpadu di Sekolah Dasar. Jurnal Pendidikan: Teori, Penelitian, Dan Pengembangan, 3(12), 1572-1582. https://doi.org/10.17977/jptpp.v3i12.11796.

Pangesti, K. I., Yulianti, D., \& Sugianto. (2017). Bahan Ajar Berbasis STEM (Science, Technology, Engineering, and Mathematics) untuk Meningkatkan Penguasaan Konsep Siswa SMA. Unnes Physics Education Journal, 6(3), 54-58. https://doi.org/10.15294/upej.v6i3.19270.

Permata, A., \& Bhakti, Y. B. (2020). Keefektifan Virtual Class dengan Google Classroom dalam Pembelajaran Fisika Dimasa Pandemi Covid-19. JIPFRI (Jurnal Inovasi Pendidikan Fisika Dan Riset Ilmiah), 4(1), 27-33. https://doi.org/10.30599/jipfri.v4i1.669.

Prananda, G., Saputra, R., \& Ricky, Z. (2020). Meningkatkan Hasil Belajar Menggunakan Media Lagu Anak Dalam Pembelajaran IPA Sekolah Dasar. JURNAL IKA, 8(2), 304-314. https://doi.org/10.36841/pgsdunars.v8i2.830.

Prasetyo, A. A., \& Nabillah, T. (2019). Faktor Penyebab Rendahnya Hasil Belajar Siswa. Sesiomadika, 2(3), 659663. https://journal.unsika.ac.id/index.php/sesiomadika/article/view/2685/1908.

Pratiwi, E. W. (2020). Dampak Covid-19 Terhadap Kegiatan Pembelajaran Online Di Perguruan Tinggi Kristen Di Indonesia. Perspektif Ilmu Pendidikan, 34(1), 1-8. https://doi.org/10.21009/pip.341.1.

Ricardo, R., \& Meilani, R. I. (2017). Impak Minat dan Motivasi Belajar Terhadap Hasil Belajar Siswa. Jurnal Pendidikan Manajemen Perkantoran, 2(2), 79. https://doi.org/10.17509/jpm.v2i2.8108.

Riwahyudin, A. (2015). Pengaruh Sikap Siswa Dan Minat Belajar Siswa Terhadap Hasil Belajar Ipa Siswa Kelas V Sekolah Dasar Di Kabupaten Lamandau. Jurnal Pendidikan Dasar, 6(1), 11. https://doi.org/10.21009/jpd.061.02.

Rizqi, A. T., \& Sumantri, M. (2019). Hubungan Antara Motivasi Belajar Dan Pola Asuh Orang Tua Terhadap Hasil Belajar IPA. Jurnal Imiah Pendidikan Dan Pembelajaran, 3(2), 145-154. http://dx.doi.org/10.23887/jipp.v3i2.18071.

Roebianto, A. (2020). The Effects of Student's Attitudes and Self-Efficacy on Science Achievement. Jurnal Pengukuran Psikologi Dan Pendidikan Indonesia (JP3I), 9(1), 1-10. 
https://doi.org/10.15408/jp3i.v9i1.14490.

Rosalina, L., \& Junaidi, J. (2020). Hubungan Minat Belajar Dengan Hasil Belajar Pada Pembelajaran Sosiologi Pada Kelas XII IPS di SMAN 5 Padang. Jurnal Sikola: Jurnal Kajian Pendidikan Dan Pembelajaran, 1(3), 175181. https://doi.org/10.24036/sikola.v1i3.24.

Rosiana, L. D. (2018). Hubungan Motivasi Belajar dan Sumber Belajar dengan Hasil Belajar IPA Kelas V. Joyful Learning Journal, 7(2), 19-26. https://doi.org/10.15294/jlj.v7i2.24432.

Rumhadi, T. (2017). Urgensi Motivasi dalam Proses Pembelajaran. Jurnal Diklat Keagamaan, 11(1), 33-41. http://journal.uin-alauddin.ac.id/index.php/adabiyah/article/view/321.

Safitri, Y. A., Baedowi, S., \& Setianingsih, E. S. (2020). Pola Asuh Orang Tua di Era Digital Berpengaruh Dalam Membentuk Karakter Kedisiplinan Belajar Siswa Kelas IV. MIMBAR PGSD Undiksha, 8(3), 508-514. https://doi.org/10.23887/jjpgsd.v8i3.28554.

Sari, F. K., Rakimahwati, R., \& Fitria, Y. (2019). Hubungan Minat dengan Hasil Belajar Peserta Didik Pada Pelajaran Matematika Kelas VI SDN 25 Jati Tanah Tinggi. Journal of Elementary Education, 3(2). https://doi.org/10.31004/basicedu.v3i2.18.

Sidiq, D. A. N., Fakhriyah, F., \& Masfuah, S. (2020). Hubungan Minat Belajar Ipa Siswa Kelas V Sd Negeri 2 Pelemkerep Terhadap Hasil Belajar Selamapembelajaran Daring. Progres Pendidikan, 1(3), 243-250. https://doi.org/10.29303/prospek.v1i3.31.

Steven RTerrell Ph D. (2014). Introduction to the special section of the Internet in Higher Education: The American Educational Research Association's Online Teaching and Learning Special Interest Group. The Internet and Higher Education, 21, 59. https://doi.org/10.1016/j.iheduc.2014.01.001.

Sugiartini, N. K., Pudjawan, K., \& Renda, N. T. (2019). Hubungan Pola Asuh Orang Tua dan Rasa Percaya Diri Terhadap Hasil Belajar IPA Kelas V. Mimbar PGSD, 5(2), 171. https://doi.org/10.23887/ika.v17i2.19853.

Wulandari, A. P., \& Renda, N. T. (2020). Hubungan Antara Pola Asuh Orang Tua dengan Motivasi Belajar Matematika Siswa. Mimbar Ilmu, 25(2), 90. https://doi.org/10.23887/mi.v25i2.26068.

Wulandari, S., Marhadi, H., \& Antosa, Z. (2017). Hubungan Minat Belajar dengan Hasil Belajar IPS Siswa Kelas IV SD Negeri Gugus III Kecamatan Rumbai Kota Pekanbaru. Joyful Learning Journal, 6(3), 1-11. https://doi.org/10.15294/jlj.v6i3.15207.

Ya-hsunTsai, Lin, C., Hong, J., \& Kai-hsin Tai. (2018). The effects of metacognition on online learning interest and continuance to learn with MOOCs. Computers \& Education, 121, 18-29. https://doi.org/10.1016/j.compedu.2018.02.011.

Yulianingsih, W., Suhanadji, S., Nugroho, R., \& Mustakim, M. (2020). Keterlibatan Orangtua dalam Pendampingan Belajar Anak selama Masa Pandemi Covid-19. Jurnal Obsesi : Jurnal Pendidikan Anak Usia Dini, 5(2), 1138-1150. https://doi.org/10.31004/obsesi.v5i2.740. 